\title{
BEHAVIORAL ASSESSMENT OF CHILDREN AT RISK OF CENTRAL AUDITORY PROCESSING DISORDER WITHOUT READING DEFICITS
}

\author{
Prawin Kumar, Niraj Kumar Singh, Vipin Ghosh P.G. \\ Department of Audiology, All India Institute of Speech and Hearing, Mysore-06, Karnataka, India
}

Corresponding author: Prawin Kumar, Lecturer in Audiology, Department of Audiology, All India Institute of Speech and Hearing, Manasagangothri, Mysore-570006, Karnataka, India, Phone No: +91 9886833741, Fax: +91821 2510515, e-mail: prawin_audio@rediffmail.com

\begin{abstract}
Background: Auditory processing abilities in children with dyslexia and reading disabilities have been widely studied using various behavioral and electrophysiological measures. However explorations in children with (C)APD without reading disability are lacking, and the present study was designed to fill that gap.

Materials and method: The study comprised an experimental group and a control group, the former having 15 children at risk of (C)APD without reading difficulties and the latter 15 typically developing children. Behavioral tests for (C)APD were administered to participants in both groups, and included the gap detection test (GDT), pitch pattern test (PPT), dichotic consonant vowel test (DCV), speech perception in noise (SPIN), and masking level difference (MLD) test.
\end{abstract}

Results: Children who were at risk of (C)APD without reading deficit displayed higher thresholds in GDT and gained poorer scores on PPT as well as SPIN when compared to the group of typically developing children. However, the performance on MLD and DCV were comparable between the groups.

Conclusions: The present study suggests a combination of GDT, PPT, and SPIN as a possible sensitive tool in clinics for indicating central auditory deficits in children at risk of (C)APD without reading deficits. DCV and MLD were not sensitive.

Keywords: central auditory processing disorders $\bullet$ gap detection test $\bullet$ pitch pattern test $\bullet$ speech in noise test $\bullet$ dichotic CV test • masking level difference test $\bullet$ early reading skills

\section{EVALUACIÓN DEL COMPORTAMIENTO DE LOS NIÑOS SIN PROBLEMAS DE LECTURA Y CON RIESGO DE SUFRIR TRASTORNOS DEL PROCESAMIENTO AUDITIVO CENTRAL}

\section{Resumen}

Introducción: El tema de la capacidad del procesamiento auditivo en los niños con problemas de dislexia y de lectura se ha estudiado ampliamente con ayuda de varias mediciones de comportamiento y pruebas electrofisiológicas. Sin embargo, faltan estudios sobre los niños con trastornos centrales del procesamiento auditivo [(Central) Auditory Processing Disorders - (C) $\mathrm{ADP}]$ que saben leer. El objetivo del presente estudio ha sido el de llenar este vacío.

Materiale y métodos: El estudio se ha realizado con participación del grupo experimental y grupo de control. El primer grupo estaba formado por 15 niños en situación de riesgo de (C) APD sin dificultad de lectura. El segundo contaba con 15 niños con desarrollo típico. Ambos grupos fueron sometidos a pruebas de diagnóstico de conducta para detectar (C) APD, incluyendo la prueba de detección de pausas en el ruido (gap detection test- GDT), prueba de patrones de tonos (pitch pattern test- PPT), prueba de audición dicótica de reconocimiento de consonantes y vocales (dichotic consonant-vowel test - DCV), percepción del habla en el ruido (speech percepction in noise - SPIN) y prueba para evaluación de diferencias en los niveles de enmascaramiento (masking level difference test - MLD).

Resultados: Los niños sin problemas de lectura, pero pertenecientes al grupo de riesgo de (C) APD, mostraron umbrales GDT más altos y resultados en las pruebas PPT y SPIN peores que los niños con un desarrollo típico. Sin embargo, los resultados de las pruebas MLD y DCV han resultado similares en ambos grupos.

Conclusiones: Los resultados de los estudios arriba mencionados sugieren que una combinación de pruebas de GDT, PPT y SPIN puede convertirse en una herramienta clínica sensible para la detección de trastornos del procesamiento auditivo central 
en los niños del grupo de riesgo (C) APD que no tienen dificultades ni de lectura, ni de escritura. Las pruebas DCV y MLD no parecen ser sensibles.

Palabras clave: trastornos del procesamiento auditivo central, prueba de detección de pausas en el ruido (gap detection testGDT) • prueba de patrones de tonos (pitch pattern test - PPT) • percepción del habla en ruido (speech percepction in noise - SPIN) • prueba de audición dicótica de reconocimiento de consonantes y vocales (dichotic consonant-vowel test - DCV) - prueba para evaluación de diferencias en los niveles de enmascaramiento (masking level difference test - MLD) • habilidades tempranas de lectura

\section{БИХЕВИОРАЛЬНАЯ ОЦЕНКА ДЕТЕЙ, НАХОДЯЩИХСЯ ПОД УГРОЗОЙ НАРУШЕНИЙ ЦЕНТРАЛЬНОЙ СЛУХОВОЙ ПЕРЕРАБОТКИ, У КОТОРЫХ ОТСУТСТВУЮТ ПРОБЛЕМЫ С ЧТЕНИЕМ}

\section{Изложение}

Вступление: Тема умения слуховой переработки у детей с дислексией и проблемами с чтением был широко исследован с помощью разных бихевиоральных и электрофизиологических измерений. Однако не хватает исследований, касающихся детей с нарушениями центральной слуховой переработки [(Central) Auditory Processing Disorders - (C)ADP], которые умеют читать. Цель настоящей работы - заполнение этого пробела.

Материал и метод: Исследованием была охвачена экспериментальная и контрольная группа. В состав первой входило 15 детей из группы риска (C)APD без проблем с чтением. Вторая группа состояла из 15 нормально развивающихся детей. Обе группы были подвергнуты диагностическим тестам, в отношении (C)APD', в том числе тесту выявления перерывов в шуме (gap detection test - GDT), тесту образцов высоты голоса (pitch pattern test PРT), дихотическому тесту на распознание согласных и гласных (dichotic consonant-vowel test - DCV), восприятия речи в шуме (speech percepction in noise - SPIN) и тесту, оценивающему разницу в уровнях маскировки (masking level difference test - MLD).

Результаты: Дети, у которых отсутствовали проблемы с чтением, но которые принадлежали к группе риска (С) $\mathrm{APD}$, проявляли высшие пороги GDT и худшие результаты в тестах PPT и SPIN по сравнению с нормально развивающимися детьми. Однако эффекты в тестах MLD и DCV были сравнимыми в двух группах.

Выводы: Результаты настоящих исследований показывают, что объединение тестов GDT, PPT и SPIN может оказаться чутким клиническим инструментом для выявления центральных нарушений слуховой переработки у детей из группы риска (C)APD, у которых отсутствуют проблемы с чтением и писанием. DCV и MLD не оказались чуткими.

Ключевые слова: нарушения центральной слуховой обработки, тест выявления перерыва в шуме (gap detection test) • восприятие речи в шуме (speech percepction in noise) • дихотический тест на распознавание согласных и гласных (dichotic consonant-vowel test) • тест оценивающий разницу в уровнях маскировки (masking level difference test) • ранее умение чтения

\section{BEHAWIORALNA OCENA DZIECI ZAGROŻONYCH ZABURZENIAMI CENTRALNEGO PRZETWARZANIA SŁUCHOWEGO, U KTÓRYCH NIE WYSTĘPUJĄ PROBLEMY Z CZYTANIEM}

\section{Streszczenie}

Wstęp: Temat umiejętności przetwarzania słuchowego u dzieci z dysleksją i problemami z czytaniem został szeroko zbadany za pomocą różnorodnych pomiarów behawioralnych i elektrofizjologicznych. Brakuje jednak badań na temat dzieci z centralnymi zaburzeniami przetwarzania słuchowego [(Central) Auditory Processing Disorders - (C)APD] potrafiących czytać. Celem niniejszej pracy było wypełnienie tej luki.

Materiał i metody: Badaniem objęto grupę eksperymentalną i grupę kontrolną. W skład tej pierwszej wchodziło 15 dzieci z grupy ryzyka (C)APD bez trudności w czytaniu. Druga grupa składała się z 15 typowo rozwijających się dzieci. Obie grupy zostały poddane diagnostycznym testom behawioralnym pod kątem (C)APD', w tym testowi wykrywania przerw w szumie (gap detection test - GDT), testowi wzorców wysokości (pitch pattern test - PPT), rozdzielnousznemu testowi na rozpoznanie spółgłosek 
i samogłosek (dichotic consonant-vowel test - DCV), percepcji mowy w hałasie (speech percepction in noise - SPIN) i testowi oceniającemu różnice w poziomach maskowania (masking level difference test - MLD).

Wyniki: Dzieci, u których nie występowały problemy z czytaniem ale należały do grupy ryzyka (C)APD, wykazywały wyższe progi GDT i gorsze wyniki w testach PPT i SPIN niż typowo rozwijające się dzieci. Jednak efekty w testach MLD i DCV były porównywalne w obu grupach.

Wnioski: Wyniki niniejszych badań sugerują, że połączenie testów GDT, PPT i SPIN może okazać się czułym narzędziem klinicznym do wykrywania ośrodkowych zaburzeń przetwarzania słuchowego u dzieci z grupy ryzyka (C)APD, u których nie występują trudności w czytaniu i pisaniu. DCV i MLD nie okazały się czułe.

Słowa kluczowe: zaburzenia centralnego przetwarzania słuchowego, test wykrywania przerwy w szumie (gap detection test) • test wzorców wysokości (pitch pattern test) • percepcja mowy w hałasie (speech percepction in noise) • rozdzielnouszny test na rozpoznanie spółgłosek i samogłosek (dichotic consonant-vowel test) • test oceniający różnice w poziomach maskowania (masking level difference test) • wczesna umiejętność czytania

\section{Background}

(Central) auditory processing refers to the perceptual processing of auditory information in the central nervous system (CNS) and the underlying neurobiologic activity that incidentally gives rise to measurable auditory evoked electrophysiologic potentials. CAP includes the auditory mechanisms that perform the following abilities or skills: sound localization and lateralization; auditory discrimination; auditory pattern recognition; temporal aspects of audition, including temporal integration, temporal discrimination, temporal ordering, and temporal masking; auditory performance in competing acoustic signals; and auditory performance with degraded acoustic signals [1-3].

(Central) auditory processing disorder [(C)APD] refers to difficulties in the perceptual processing of auditory information in the CNS as demonstrated by poor performance in one or more of the above skills. (C)APD has been shown to be an umbrella term incorporating deficits in one or more of the above mentioned processes and hence present consensus statements and guidelines $[4,5]$ recommend the diagnosis of (C)APD to be made using a test battery approach using psychophysical (behavioral) and/or electrophysiological measures that have been shown to be sensitive, specific, and efficient for identification of disorders of central auditory nervous system (CANS).

The efficacy of behavioral tests has been extensively researched and behavioral tests have been shown to be useful in the diagnosis of different aspects of (C)APD. These include the gap detection test (GDT), masking level difference (MLD), pitch pattern test (PPT), duration pattern test (DPT), and dichotic speech tests. King et al. investigated the performance of 11 young adults with dyslexia on auditory processing tasks such as the frequency pattern test (FPT) and DPT and found that 5 of 11 subjects failed both tests [6]. Other studies have used different behavioral tasks such as auditory discrimination for tones [7], identification of rapidly presented high-low frequency tones $[7,8]$, or gap detection [8] to investigate auditory processing in children and adults with reading disorders. They found a significant difference in scores obtained by individuals with reading disorder and individuals without reading disorder. In contrast, Walker et al. found significant difference between adults with reading disorders and a control group for DPT scores, but not for FPT scores [9].
Iliadou et al. [10] investigated hemispheric laterality in adults with dyslexia, (C)APD, and co-morbidity of both. Dichotic digit testing was carried out and the results were compared with those from an age-matched control group. While the individuals in the control group and adults with (C)APD alone exhibited right hemisphere dominance, left hemisphere dominance was observed in adults with comorbidity of (C)APD and dyslexia. The group of individuals with dyslexia alone was marked by an absence of cerebral dominance. In addition, individuals in all groups except the control group demonstrated deficiencies in auditory performance in the presence of a competing auditory signal. Moncrieff and Musiek [11] also compared the performance of children with dyslexia against typically developing children on the dichotic digit test, dichotic consonant-vowel test, and competing words test taken from SCAN, which is a sub-test for auditory processing disorders. The performances of the children from the two groups were significantly different on dichotic tests; nonetheless the competing word test was reported to demonstrate higher sensitivity than the dichotic tests.

The above studies have highlighted the efficiency of behavioral tests in identification of auditory processing deficits in children with dyslexia and reading problems. However, (C)APD is only one aspect of the problems in these children. Further, there is a dearth of studies exploring tests to identify the group of children who exhibit symptoms of (C)APD but not reading disability. While abnormal temporal processing and dichotic listening have been reported in children with reading disorders, there is a lack of studies investigating the auditory processing in children who exhibit symptoms of (C)APD without reading disorders using behavioral tests. This suggests the need for investigating behavioral tests for auditory processing in children at risk of (C)APD but without reading deficits.

\section{Materials and Method}

\section{Participants}

The study was conducted after approval from the Institutional Review Board of the All India Institute of Speech and Hearing, Mysore, India. The study included 336 schoolgoing children of age 8 to 12 years. Initial screening for (C)APD using the 'screening checklist for auditory processing' (SCAP) [12] was carried out for all participants. 
SCAP was adopted for the purpose of screening since the sensitivity and specificity of the tests in identifying children with (C)APD is determined to be $71 \%$ and $68 \%$ respectively [13].

Among the 51 children who were identified as at risk of (C)APD were 15 children who passed an Indian adaptation of the 'early reading skills' (ERS) test [14]; these 15 were selected randomly and placed in the experimental group in order to rule out the existence of reading deficits. The mean age of participants in the experimental group was 9.33 years. As a control, we used 15 age matched typically developing children with a mean age of 9.86 who were not at risk of (C)APD and who passed the ERS test. All participants were recruited to the study on a non-payment basis; written informed consent was obtained from their parents. In addition, participants in both groups had normal hearing sensitivity defined by pure-tone thresholds within $15 \mathrm{~dB} \mathrm{HL}$ in the frequency range 0.25 to $8 \mathrm{kHz}$. They had normal click-evoked ABR findings and normal middle ear function.

\section{Procedure}

Test stimuli for all (C)APD tests were routed from a personal computer through a two-channel clinical audiometer (Madsen Orbiter OB-922) with TDH-39 supra-aural headphones at an intensity of $40 \mathrm{~dB}$ SL (ref: PTA). Initially, a $1 \mathrm{kHz}$ calibration tone was presented to the subject's ear through the earphones and the VU meter was adjusted to zero. At least two practice items per test were presented before commencement of each of the tests in order to ensure understanding of the task. Listening breaks were also given periodically throughout the testing session.

All 336 participants underwent screening for identification of (C)APD using SCAP. A score in excess of 6 on this screening checklist, as has been recommended by its developers, was considered to be positive for risk of (C)APD. The participants who obtained such scores were further assessed for their reading abilities using the ERS test. The different sub-tests included in the ERS test for assessing the reading process are auditory identification, auditory recall, visual discrimination, auditory discrimination, phoneme grapheme correspondence, and structural analysis. All participants in the experimental group as well as control group possessed grade-appropriate reading skills according to the ERS test results. Screening for (C)APD as well as ERS testing were both administered in silent rooms within the participants' schools.

Upon fulfillment of the inclusion criteria, behavioral tests for the identification of deficits pertaining to (C)APD were carried out on children in both the experimental as well as the control groups. These included the pitch pattern test (PPT) developed by Shivani [15], gap detection test (GDT) developed by Shivaprakash [16], dichotic consonant vowel test (DCV) developed by Yathiraj [17], speech perception in noise (SPIN), and masking level difference (MLD) test. The PPT includes 30 test items in addition to 6 practice items. Each item consists of three pure tones each of $500 \mathrm{~ms}$ duration which are separated by an inter-stimulus interval of $300 \mathrm{~ms}$. The tone frequencies are $880 \mathrm{~Hz}$ and $1430 \mathrm{~Hz}$, resulting in two alike and one different tone in each item set. Subjects were instructed to repeat the pattern of sequences verbally. The GDT consists of 60 stimuli with 4 practice items and 6 catch trials. The stimuli are a sequence of $300 \mathrm{~ms}$ noise bursts separated by $750 \mathrm{~ms}$ silence with a gap inserted in one of the noise bursts. The duration of the gap reduces progressively from $20 \mathrm{~ms}$ to $1 \mathrm{~ms}$. The task of the participant was to identify the number in the sequence which possessed the gap.

DCV stimuli were presented at $40 \mathrm{~dB}$ above the PTA and participants were instructed to write down the stimuli as they were heard. Scores for right ear and left ear were separately analyzed along with double correct scores. For the SPIN test, the Kannada word list developed by Yathiraj and Vijayalakshmi [18] was delivered at $0 \mathrm{~dB}$ signal to noise (speech-shaped noise) ratio and the participants were asked to repeat the words. Exactly 25 words were presented to each ear at the specified signal to noise ratio and the SPIN score was the percentage of words identified correctly for each ear. For the MLD test, the signal and noise were given in both homophasic and antiphasic conditions; the test was carried out at $500 \mathrm{~Hz}$ as well as at $1 \mathrm{kHz}$. The difference in threshold between homophasic and antiphasic conditions was considered as the amount of masking level difference at each frequency. All the tests were administered in an acoustically treated single room set-up with ambient noise levels within the acceptable limits as per ANSI recommendations [19].

A commercially available statistical tool, Statistical Package for Social Sciences (SPSS) version 16.0, was used for statistical analysis in order to investigate the differences between the control and experimental groups. The analysis included descriptive statistics and multivariate analysis of variance (MANOVA).

\section{Results}

Means and standard deviations (SD) were calculated for the scores of GDT, PPT, SPIN, MLD, and DCV test, and these are depicted in Table 1.

MANOVA was carried out to investigate the existence of any statistically significant difference between the groups. The results of MANOVA revealed a significant main effect of groups on the scores of GDT $[\mathrm{F}(1,58)=12.80, p<0.05$; partial eta squared $=0.18]$. Similarly, a significant main effect of groups on the scores of PPT $[F(1,58)=4.11, p<0.05$; partial eta squared $=0.06]$ and $\operatorname{SPIN}[\mathrm{F}(1,58)=5.53, p<0.05$; partial eta squared $=0.08]$ was also revealed. However, the results revealed no significant main effect of groups on the single correct scores of right ear $[\mathrm{F}(1,28)=2.22, p>0.05]$, left ear $[\mathrm{F}(1,28)=4.15, p>0.05]$, as well as the double correct scores $[\mathrm{F}(1,28)=1.24, p>0.05]$, on the DCV test. Likewise, there also existed no significant main effect of groups on MLD at both $500 \mathrm{~Hz}[\mathrm{~F}(1,28)=2.15, p>0.05]$ as well as $1 \mathrm{kHz}[\mathrm{F}(1,28)=1.19, p>0.05]$. The box plots depicting the PPT scores and DCV scores are given in Figure 1. Figures 2 and 3 represent the box plots for SPIN scores and GDT thresholds respectively.

In summary, the group of children at risk of (C)APD but without underlying reading deficits produced poorer scores on GDT, PPT, and SPIN. However, the single correct scores 
Kumar et al. - Behavioral Assessment of Children at Risk of Central Auditory Processing Disorder...

Table 1. Mean and standard deviations (SD) of behavioral test scores in both control and experimental groups

\begin{tabular}{|c|c|c|c|c|c|}
\hline \multirow{2}{*}{ Tests } & \multicolumn{2}{|c|}{ Control group } & \multicolumn{2}{|c|}{ Experimental group } & \multirow{2}{*}{$p$ value } \\
\hline & Mean & SD & Mean & SD & \\
\hline GDT (ms) & 3.40 & 0.81 & 5.33 & 2.84 & $0.001^{*}$ \\
\hline PPT (total raw score $=30$ ) & 19.60 & 7.38 & 15.73 & 7.39 & $0.047^{*}$ \\
\hline RE-SCS & 16.47 & 6.36 & 12.93 & 6.63 & $0.147^{\star \star}$ \\
\hline LE-SCS & 14.20 & 4.74 & 10.27 & 5.79 & $0.051^{\star *}$ \\
\hline DCS $($ total raw score $=30)$ & 7.067 & 4.63 & 5.13 & 4.87 & $0.275^{\star *}$ \\
\hline SPIN (\%) & 70.40 & 5.21 & 66.80 & 6.57 & $0.022^{*}$ \\
\hline MLD - $500 \mathrm{~Hz}(\mathrm{~dB})$ & 6.67 & 2.44 & 8.00 & 2.54 & $0.153^{\star \star}$ \\
\hline$M L D-1 \mathrm{kHz}(\mathrm{dB})$ & 6.67 & 2.44 & 7.67 & 2.58 & $0.285^{\star \star}$ \\
\hline
\end{tabular}

ms - millisecond; RE-SCS - right ear - single correct score; LE-SCS - left ear - single correct score; DCS - double correct score; ${ }^{*} p<0.05 ;{ }^{* *} p>0.05$.

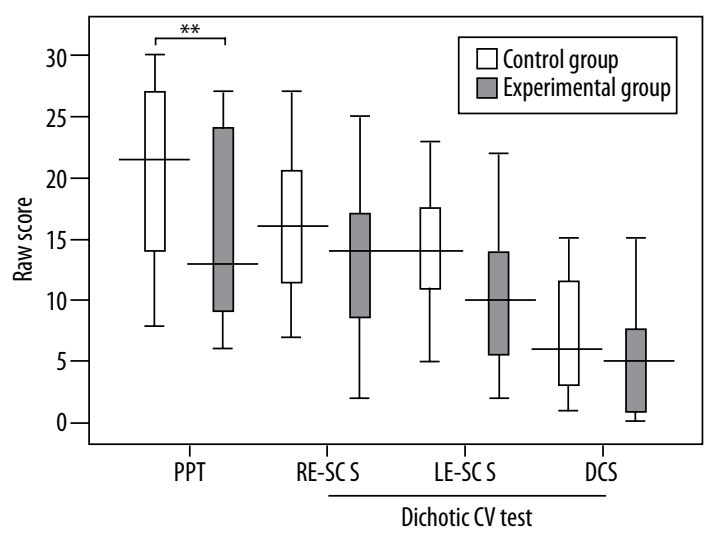

Figure 1. Raw scores obtained in pitch pattern test (PPT) and dichotic consonant vowel (DCV) test. (Key: ** $p<0.05$; RE-SCS $=$ single correct score for right ear; LE-SCS = single correct score for left ear; DCS = double correct score)

of the right ear and the left ear, as well as the double correct scores on DCV, were comparable between the groups.

\section{Discussion}

Using behavioral tests of auditory processing the performance of the group of children at risk of (C)APD but without reading deficits was compared with a group of children who were not at risk of (C)APD. While some of the test results could clearly demarcate between the two groups, others failed to show any difference.

The group of children at risk of (C)APD exhibited higher GDT thresholds compared with children who were not at risk of (C)APD. This is in agreement with results reported previously in other clinical populations [7,9,20-23]. Ingelghem et al. [22] tested rapid temporal processing efficiency in individuals with dyslexia using an auditory gap detection test and reported elevated thresholds in such individuals. Tallal [7] studied the efficiency of perceiving temporal order in individuals with reading impairment.

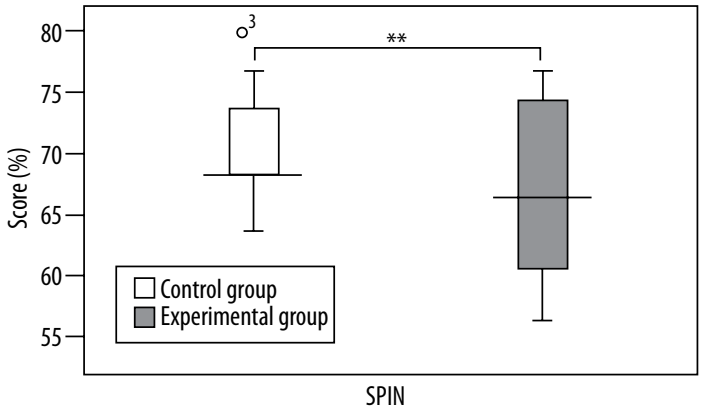

Figure 2. Scores (\%) obtained in SPIN (speech perception in noise) test. ( $\left.{ }^{\star *} p<0.05\right)$

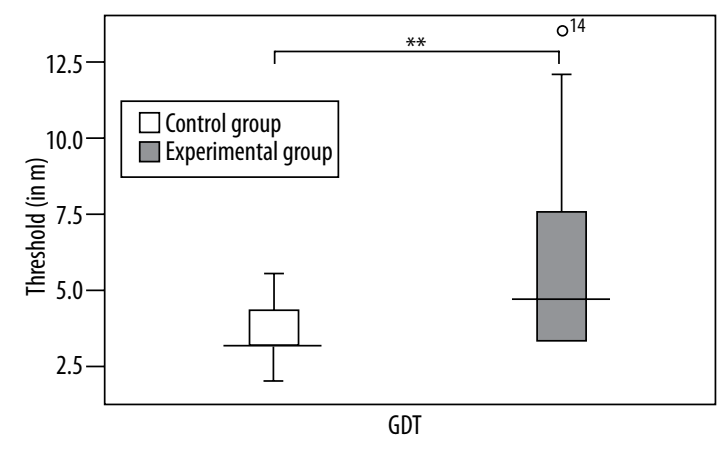

Figure 3. Thresholds (ms) in gap detection test (GDT). $\left({ }^{* *} p<0.05\right)$

Non-verbal auditory perceptual tests were used and the results revealed a significantly higher rate of errors in the performance of children with reading impairment. The study concluded that certain reading impairments may be related to auditory perceptual deficits. Thus the results are suggestive of a generalized temporal processing deficit in these children.

The children at risk of (C)APD were found to score significantly poorer on PPT than children who were not at risk. Though there are no studies using the population 
explored in the present study, the studies on other related populations have revealed equivocal findings. While Singh and Kumar [24] reported poorer performance among children with dyslexia compared to their typically developing peers, Walker et al. [9] reported no difference in performance on a frequency pattern test between individuals with reading disorders and healthy controls. The differences in the findings might be attributed to the use of different population in the two studies. Much like the findings on GDT, the findings on PPT in the present study appears to indicate the existence of temporal processing deficits among children at risk of (C)APD without associated reading deficits.

The group of children at risk of (C)APD without associated reading deficits were compared to the group of typically developing children for performance on SPIN and the results revealed a significant difference between the groups. The scores obtained by the children who were at risk of (C)APD were significantly lower than those obtained by typically developing children. Although there is dearth of reports regarding the performance of the population of the present study on SPIN, investigations have been conducted in various other related clinical populations. Chermak et al. [20] investigated word identification in the presence of noise among adults with learning disability and reported significantly reduced performance in individuals with learning disability compared to age-matched controls. The results suggested a greater susceptibility of individuals with learning disability to acoustic masking. They concluded that the auditory or language deficits observed in such individuals may be a consequence of an underlying acoustic disorder. Similar deficits in speech perception in noise were also reported in another study [25] in individuals with learning disability. Thus, drawing parallels with the previously reported studies, it may be assumed that greater susceptibility of individuals with (C) APD without reading deficits to acoustic masking may be due to a deficit in an underlying mechanism that makes use of different features of the signals to suppress unwanted signals, and this may be affecting the performance in noise of children who are at risk of (C)APD.

Masking level differences were calculated at $500 \mathrm{~Hz}$ and $1 \mathrm{kHz}$ for all the participants and the results were compared between the groups. The results revealed that the MLD was comparable between the children who were at risk of (C)APD and those who were not at risk of (C)APD. The findings of the present study are in congruence with those reported previously, although in a slightly different population - children with a language-learning disability [26]. The earlier work reported a similar lack of difference in MLD results between children with language-learning deficits and their typically developing peers, suggesting a lack of sensitivity of MLD in identifying auditory processing deficits. A similar lack of difference in results of MLD has been shown among children with dyslexia [21] and adults with reading disorders [23]. This might suggest a pathology at the cerebral level in such populations, as MLD's lack of sensitivity in identifying pathologies at such high levels has been demonstrated by previous studies [27]. Thus, it might be safe to assume that MLD is not sensitive enough to identify individuals with auditory processing disorders.
Both SPIN and MLD make use of masking phenomena, but the performance of children at risk of (C)APD without associated reading deficits was different on the two tests. While SPIN scores in the experimental group were dramatically poorer than typically developing children, there was no difference in performance on MLD. This might be attributed to certain facts associated with the two tests. First, SPIN has been shown to be affected by pathologies at any point in the auditory nervous system, as opposed to the relative insensitivity of MLD to more cortical or cerebral pathologies $[27,28]$ Second, there is a clear difference between the tests in both the stimulus and the task. While MLD is only a detection task for tonal stimuli in the presence of noise, SPIN requires an individual to identify the words in the presence of noise, making it a more complex task than MLD. Thus, a combination of the two could explain the difference in findings on the two tests.

The comparison of performance in the DCV test revealed a lack of statistically significant difference between the groups. While there have been limited investigations on the population used in the present study, the performance of other related clinical populations using dichotic tests has been extensively studied. The results of the present study are discordant with various other studies reported previously in dyslexia [29-31]. While children with dyslexia were reported to demonstrate significantly poorer performance on the DCV test [29,31], a similar poor performance was reported on the dichotic digit test [30].

The above studies which reported the presence of binaural integration problems were carried out on children with dyslexia, for which auditory processing deficit may be a causative factor. Nevertheless, such a report in children at risk of (C)APD without any associated deficits is lacking in the literature. Hence the difference in findings of the previous studies on dichotic tasks can be attributed to the different target populations. The results of the present study reveal a lack of binaural integration deficits among children at risk of (C)APD without associated reading problems. Hence it can be assumed that binaural integration is a crucial auditory process for the development of age-appropriate reading efficiency.

\section{Conclusions}

Children at risk of (C)APD without reading deficit exhibited higher thresholds in the gap detection test (GDT) and yielded poorer scores on the pitch pattern test (PPT) and speech in noise test (SPIN) when compared to a group of typically developing children. However, the results of a masking level difference (MLD) test and a dichotic consonant vowel (DCV) test were comparable between the groups. The study hence demonstrates that a combination of GDT, PPT, and SPIN could be used clinically to detect the subtle auditory processing deficits in children at risk of (C)APD without reading deficits. However DCV and MLD did not show much sensitivity in this regard. The present study initiates research in children at risk of (C) APD without reading deficits which will help in developing suitable test strategies for understanding the origin of auditory deficits in such children, along with the development of appropriate rehabilitation strategies. 


\section{Acknowledgements}

The authors acknowledge the head of the Department of Audiology, AIISH, for allowing us the use of facilities and equipment. We express our sincere gratitude to the participants of the study.

\section{Conflict of Interest and Source of Funding}

The authors do not have any conflict of interest. This paper is an outcome of a project "Relationship between electrophysiological sub-cortical processing of speech and behavioral tests of central auditory function in children with (central) auditory processing disorder", funded by the AIISH Research Fund.

\section{References:}

1. American Speech-Language-Hearing Association. Central auditory processing: Current status of research and implications for clinical practice. Am J Audiol, 1996; 5: 41-54.

2. Bellis TJ. Assessment and management of central auditory processing disorders in the educational setting. Science to practice: $2^{\text {nd }}$ ed. Clifton Park (NY): Delmar Learning; 2003.

3. Chermark GD, Musiek FE. Central auditory processing disorders: New perspectives. San Diego; Singular, 1997.

4. American Academy of Audiology. Guidelines for the diagnosis, treatment, and management of children and adults with central auditory processing disorders. 2010; Available from: http://www.audiology.org/resources/documentlibrary/documents/CAPD guidelines8-2010.pdf.

5. American Speech-Language-Hearing Association. (Central) auditory processing disorders (technical report) 2005. Available from: http://www.asha.org/docs/html/TR2005-00043.html.

6. King WM, Lombardino LJ, Crandell CC, Leonard CM. Comorbid auditory processing disorder in developmental dyslexia. Ear Hear, 2003; 24(5): 448-56.

7. Tallal P. Auditory temporal perception, phonics and reading disabilities in children. Brain Lang, 1980; 9(3): 182-98.

8. Farmer ME, Klein R. Auditory and temporal processing in dyslexic and normal readers. Ann NY Acad Sci, (1993); 14: 339-41.

9. Walker MM, Shinn JB, Cranford JL, Givens GD, Holbert D. Auditory temporal processing performance of young adults with reading disorders. J Speech Lang Hear Res, 2002; 45(3): 598-605.

10. Iliadou V, Kaprinis S, Kandylis D, Kaprinis GS. Hemispheric laterality assessment with dichotic digits testing in dyslexia and auditory processing disorder. Int J Audiol, 2010; 49(3): 247-52.

11. Moncrieff DW, Musiek FE. Interaural asymmetries revealed by dichotic listening tests in normal and dyslexic children. J Am Acad of Audiol, 2002; 13(8): 428-37.

12. Yathiraj A, Mascharanas K. Audiological profile of children with suspected auditory processing disorder. JISHA, 2004; 18: 5-13.

13. Muthuselvi T, Yathiraj A. Utility of Screening Checklist for Auditory Processing (SCAP) in detecting (C)APD children. Student research at A.I.I.S.H Mysore (article based on dissertation done at AIISH), Part-A, Audiology, 2009; 7: 159-75.

14. Loomba $\mathrm{M}$. Descriptive analysis of the sequential progression of English reading skills among Indian children. Unpublished dissertation, University of Mysore, Mysore; 1995.

15. Shivani T. Maturational effect of pitch pattern sequence test. Unpublished independent project, University of Mysore, Mysore; 2003.
16. Shivaprakash S. GDT: Development of norms. Unpublished independent project, University of Mysore, Mysore; 2003.

17. Yathiraj A. Dichotic CV test - revised. Developed at Department of Audiology, All India Institute of Speech and Hearing, Mysore; 1999.

18. Yathiraj A, Vijayalakshmi CS. Phonemically balanced word list. Developed at Department of Audiology, All India Institute of Speech and Hearing, Mysore; 2005.

19. American National Standard: Maximum Permissible Ambient Noise Levels for Audiometric Test Rooms. New York: American National Standards Institute, Inc., ANSI S3.1 1999; 1999.

20. Chermak GD, Vonhof MR, Bendel RB, Word identification performance in the presence of competing speech and noise in learning disabled adults. Ear Hear, 1989; 10(2): 90-93.

21. Hill NI, Bailey PJ, Griffiths YM, Snowling MJ. Frequency acuity and binaural masking release in dyslexic listeners. J Acoust Soc Am, 1999; 106(6): 53-58.

22. Ingelghem VM, Wieringen VA, Wouters J, Vandenbussche E, Onghena P, Ghesquiere P. Psychophysical evidence for a general temporal processing deficit in children with dyslexia. Neuroreport, 2001; 12(16): 3603-7.

23. Amitay S, Ahissar M, Nelken L. Audiory processing deficits in reading disabled adults. J Assoc Res Otolaryngol, 2002; 3(3): 302-20.

24. Cameron S, Dillon H. The Listening in Spatialized Noise - Sentences test (LISN-S): comparison to the prototype LISN and results from children with either a suspected (central) auditory processing disorder or a confirmed language disorder. J Am Acad Audiol, 2008; 19(5): 377-91.

25. Singh S, Kumar P. Electrophysiological and behavioral assessment of temporal processing abilities in children with dyslexia. Dissertation based article. (in press).

26. Roush J, Tait CA. Binaural fusion, masking level differences and auditory brainstem responses in children with language learning disabilities. Ear Hear, 1984; 5(1): 37-42.

27. Lynn GE, Gilroy J, Taylor PC, Leiser RP. Binaural maskinglevel differences in neurological disorders. Arch Otolaryngol, 1981; 107(6): 357-62.

28. Wong PC, Ettlinger M, Sheppard JP, Gunasekera GM, Dhar $\mathrm{S}$. Neuroanatomical characteristics and speech perception in noise in older adults. Ear Hear, 2010; 31: 471-79.

29. Moncrieff DW, Black JR. Dichotic listening deficits in children with dyslexia. Dyslexia, 2008; 14(1): 54-75.

30. Billet CR, Bellis TJ. The relationship between brainstem temporal processing and performance on tests of central auditory function in children with reading disorders. J Speech Lang Hear Res, 2011; 54: 228-42.

31. Gupta R, Kumar P. Relationship between speech evoked ALLR and dichotic CV scores in children with dyslexia. Dissertation based article. (in press). 